\title{
Pengaruh Penambahan Arang Aktif Limbah Tongkol Jagung Untuk Mengurangi Kadar Kesadahan Total
}

\author{
Awwalunisa Aliya Kusuma ${ }^{1}$, Binti Lathifaturrohmah'1, Eka Erfiana Dyah Lestari ${ }^{1}$ \\ ${ }_{1}^{1}$ Jurusan Kimia, Universitas Islam Negeri Walisongo Semarang-Indonesia \\ E-mail: awwalunisa.ak@gmail.com
}

\begin{abstract}
Abstrak
Kesadahan total dalam air adalah jumlah kalsium dan magnesium yang terlarut dalam air. Tujuan dari penelitian ini adalah untuk mengetahui kadar kesadahan sebelum serta sesudah perlakuan dengan penambahan absorben berupa arang aktif tongkol jagung. Dilakukan uji aktivitasi arang aktif dari tongkol jagung pada sampel air tanah di lingkungan Kecamatan Cepu dengan menggunakan metode kompleksometri. Kadar kesadahan total sesudah perlakuan dengan penambahan absorben menurun. Kadar rata-rata kesadahan air sumur dari 3 sampel lokasi yang diteliti sebelum perlakuan $344,376 \mathrm{mg} / \mathrm{L}$ setelah perlakuan menjadi $216,765 \mathrm{mg} / \mathrm{L}$. Berdasarkan hasil penelitian dapat diketahui bahwa penggunaan karbon aktif tongkol jagung dapat memberikan pengaruh terhadap penurunan tingkat kekeruhan serta kesadahan air tanah di lingkungan Kecamatan Cepu.
\end{abstract}

Kata kunci: Tongkol Jagung; Adsorben; Air Tanah

\section{Abstract}

Total hardness is the amount of calcium and magnesium ions dissolved in water. The purpose of this research was to determine total hardness levels before and after treatment on absorption by corn cobs active charcoal. The test method for activated charcoal from corn cobs on groundwater samples in Cepu Subdistrict uses the complexometry method. The percentage of total hardness after treatment with the addition of absorbent decreases. The average percentage of hardness soil water from 3 location sample before $344,376 \mathrm{mg} / \mathrm{L}$ to be 216, $765 \mathrm{mg} / \mathrm{L}$. Based on the results of research that can be published on how to use activated carbon corncobs can provide benefits to reduce turbidity levels and also soil water hardness in the Subdistrict Cepu.

Keywords: Corncobs; Adsorbent; Soil Water

\section{Pendahuluan}

Sungai Bengawan Solo merupakan aliran sungai terpanjang di Pulau Jawa dan merupakan sumber utama air bersih. Air sungai Bengawan Solo terkena cemaran limbah ciu dan kotoran babi oleh peternak babi yang tidak sengaja membuang limbah tersebut dan pabrik ciu yang tidak sengaja menumpahkan limbah pembuangannya sebelum diolah. Pencemaran yang terjadi pada bulan November tahun 2019 menyebabkan sekitar 16.000 pelanggan air bersih terkena dampaknya (Tim CNN, 2019). Air bersih tersebut digunakan untuk MCK, mencuci maupun makan dan minum. Pencemaran berimbas pada anak sungai yang bermuara di Sungai Bengawan Solo. Salah satunya sungai yang ikut mencemari di daerah Kecamatan Cepu. Akibatnya air tidak 
dapat disalurkan kepada masyarakat karena khawatir baku mutu standar yang ditetapkan pemerintah tidak terpenuhi.

Pencemaran di sungai Bengawan Solo bertepatan bulan November 2019 yang merupakan musim panas masyarakat Kecamatan Cepu. Sebagian besar masyarakat menggunakan air untuk konsumsi dari aliran anak sungai Bengawan Solo.

Penggalian sumur baru dilakukan sebagai solusi. Keberadaan sumur galian baru yang bertepatan di sekitar lingkungan pengeboran mempegaruhi kestabilan kandungan air dalam sumur galian baru. Sumur tersebut terletak di lingkungan kantor PPSDM Migass Cepu. Meskipun air berwarna jernih ditemukan kandungan kesadahan yang cukup tinggi. Kecamatan Cepu merupakan daerah pengunungan kapur. Kandungan air didalam tanah banyak terdapat $\mathrm{Ca}^{2+}$ dan $\mathrm{Mg}^{2+}$. Penggendapan yang cepat pada $\mathrm{Ca}$ dan $\mathrm{Mg}$ dalam air mempengaruhi metabolisme dalam tubuh. Penyumbatan yang disebabkan karena pengendapan yang cepat memunculkan penyakit batu ginjal.

Berbagai metode sederhana telah digunakan untuk menurunkan kadar kesadahan. Masyarakat umum memasak air sebelum dikonsumsi, ketika proses pemanasan, karbon dioksida dalam air keluar dan membentuk endapan kerak putih $\mathrm{CaCO}_{3}$ yang tidak larut, cara lain bisa dengan menambahkan kapur soda air yang sifatnya menyadahkan sementara (Nana Ristiana dan Dwi Astuti, 2009)

Jagung (Zea mays L.) merupakan tanaman hasil bumi terbanyak di Indonesia setelah padi. Masyarakat atau petani pengelola, umumnya menggunakan limbah hanya untuk pakan ternak, ditumpuk, atau bahkan dibakar. Pembakaran yang dilakukan di lingkungan udara bebas tanpa kontrol berdampak pada gas buangan yang dihasilkan berupa SOx atau NOx. Untuk menghindari hal tersebut pemanfaatan limbah dengan dibuat arang aktif untuk absorben. Kandungan unsur karbon yang besar sekitar $43 \%$ dinilai sangat potensial untuk dibuat arang aktif (Siti Munfiah, 2015).

Teknik karbonasi (steam activation) umumnya digunakan untuk mengaktivasi suatu adsorben. Aktivasi dilakukan pada temperatur 800-1100 ${ }^{\circ} \mathrm{C}$ dengan mengalirkan uap panas jenuh (Rahmayani dan Siswarni, 2013). Pada penelitian Amin (2016) menjelaskan aktivasi pada $400{ }^{\circ} \mathrm{C}$ pada arang berfungsi menaikan kadar karbon. Kadar karbon yang diperoleh sekitar 59,13\% (Amin dkk, 2016). Arang yang dihasilkan dari kalsinasi memliki luas permukaan yang besar dengan ukuran poripori yang ideal sehingga ketika diaplikasikan untuk mengadsorp polutan mampu menyerap fase cair atau uap. Daya adsorpsi dapat diukur dengan analisa adsorbsi isotherm.

Selama 10 tahun terakhir banyak penelitian arang aktif yang mulai dilakukan untuk mengurangi polutan yang mencemari lingkungan. Penelitian yang dilakukan Mantong, dkk (2018) menjelaskan besar pori pada arang aktif mempengaruhi kecepatan atau banyak dalam menyerap polutan dalam limbah. Pori yang dihasilkan pada arang aktif limbah tongkol jagung didapatkan setelah perlakuan aktivator. Semakin besar aktivator yang diberikan pada arang aktif, pori yang dihasilkan akan semakin besar. Penurunan nilai polutan dalam limbah juga dipengaruhi oleh lama waktu perendaman arang aktif dalam limbah (Mantong dkk, 2018).

Peneliti ingin memberikan inovasi mutakhir dimana arang aktif tersebut dibungkus dengan kantong teh celup, dan arang aktif tersebut tidak langsung terkontak dengan suatu air sadah dan mudah dipisahkan kembali dari limbah cair tersebut tanpa mengurangi kegunaan utama dari arang aktif tersebut yaitu sebagai adsorpsi untuk menurunkan kesadahannya dalam suatu air sumur galian baru.

Oleh karena itu, penelitian ini dilakukan dengan memanfaatkan limbah tongkol jagung sebagai arang aktif yang kemudian dibungkus kantong teh celup agar 
dapat mengurangi pencemaran kesadahan air.

\section{Metode Penelitian}

\section{Alat dan Bahan}

Alat yang digunakan gelas beker, batang pengaduk, erlemenyer, gelas arloji, gelas ukur, pipet ukur, corong, ayakan 200 mesh, waterbath, necara analitik, furnace, dan oven.

Bahan yang digunakan larutan buffer $\mathrm{pH}$ 10, limbah tongkol jagung, $\mathrm{HCl}$ 98\% (Merck), $\mathrm{Na}_{2}$ EDTA, EBT, dan akuades.

\section{Prosedur Kerja}

Pembuatan Arang Aktif

Limbah tongkol jagung yang diperoleh dicuci dengan air mengalir untuk menghilangkan pengotor yang masih terbawa pada limbah tersebut. Tongkol jagung dipotong kecil-kecil kemudian dikeringkan pada suhu $100{ }^{\circ} \mathrm{C}$ didalam oven sampai benar-benar kering. Tongkol jagung yang sudah kering, dipanaskan untuk menghasilkan arang dengan furnace pada suhu $400{ }^{\circ} \mathrm{C}$ selama 10 menit Arang yang diperoleh ditumbuk sampai terbentuk serbuk. Setelah berbentuk serbuk selanjutnya diayak dengan ayakan 200 mesh. Arang yang lolos dengan ayakan 200 mesh direndam dalam reagen aktivator asam yang digunakan $\mathrm{HCl} 4 \mathrm{~N}$. Selanjutnya disaring dan dicuci arang aktif dengan akuades sebanyak 3 kali sampai $\mathrm{pH}$ netral. Arang yang sudah dibilas kemudian dikeringkan dalam oven suhu $110^{\circ} \mathrm{C}$ selama $3 \mathrm{jam}$. Setelah arang aktif dalam suasana suhu ruang dimasukan dalam desikator.

\section{Pengemasan Arang Aktif}

Arang aktif tongkol jagung ditimbang dalam massa 0,5 gr. Kemudian, arang aktif tersebut dimasukan kedalam kantong teh celup komersional dengan rapih.
Uji sampel kesadahan total

Dipipet $25 \mathrm{~mL}$ sampel. Dimasukan dalam labu erlemenyer $250 \mathrm{~mL}$. Diencerkan sampai $50 \mathrm{~mL}$. Ditambahkan $2 \mathrm{~mL}$ larutan penyangga buffer $\mathrm{pH}$ 10. Ditambahkan 1-2 tetes indikator EBT. Dilakukan titrasi dengan larutan baku $\mathrm{Na}_{2}$ EDTA 0,01 M sampai terjadi perubahan warna dari merah keunguan menjadi biru.

\section{Hasil Penelitian dan Pembahasan}

\section{Analisis dengan metode kompleksometri}

Analisis yang digunakan untuk mengukur kesadahan total menggunakan metode kompleksometri. Metode tersebut sering digunakan, karena lebih sederhana dan cepat dengan hasil yang akurat untuk mengetahui titik akhir titrasi. Prinsip metode kompleksometri adalah terbentuknya ionion kompleks pada tingkat kelarutan yang tinggi dari kompleks yang dihasilkan oleh larutan EDTA. Penambahan larutan buffer dalam sampel perlu dilakukan untuk menjaga agar larutan tetap pada kondisi basa.

Indikator EBT yang mengandung ion-ion Ca dan Mg ditambahkan dalam suatu larutan dengan hasil penambahan membentuk warna merah anggur (Khopkar, 2002). Larutan EDTA yang terikat seluruhnya pada kompleks ion $\mathrm{Ca}$ dan $\mathrm{Mg}$ akan dihasilkan titik akhir titrasi larutan yang bewarna merah menjadi biru.

Reaksi:

$$
\begin{aligned}
& \mathrm{Ca}^{2+}+\mathrm{EBT} \rightarrow \mathrm{Ca}^{2+}-\mathrm{EBT}(\text { merah) } \\
& \mathrm{Ca}^{2+}-\mathrm{EBT} \rightarrow \mathrm{Ca}^{2+}-\mathrm{EDTA}+\mathrm{EBT}(\mathrm{biru}) \\
& \text { CaIn }\left(\text { merah) }+\mathrm{H}_{2} \mathrm{Y}_{2}^{-} \rightarrow \mathrm{CaY}_{2^{-}}+\right.\text {(tak } \\
& \text { berwarna) }+\mathrm{Hin}^{2-}\left(\text { biru }+\mathrm{H}^{-}\right. \\
& \mathrm{Mg}^{2+}+\mathrm{H}_{2} \mathrm{Y}_{2}^{-} \leftrightarrow \mathrm{MgY}_{2}^{-}+2 \mathrm{H}^{+} \\
& \mathrm{Ca}^{2+}+\mathrm{H}_{2} \mathrm{Y}_{2}^{-} \leftrightarrow \mathrm{CaY}_{2}^{-}+\mathrm{HIn}^{-}+\mathrm{H}^{+} \\
& \mathrm{MgIn}^{-}+\mathrm{H}_{2} \mathrm{Y}_{2}^{-} \leftrightarrow \mathrm{MgY}_{2}^{-}+\mathrm{HIn}^{-} \text {(biru) }+\mathrm{H}^{+}
\end{aligned}
$$

\section{Aktivasi arang aktif dengan $\mathrm{HCl}$}

Pengaktifan bonggol jagung dibuat dengan menghilangkan air pada tongkol jagung yaitu di oven sampai benar-benar 
kering pada suhu sekitar $110{ }^{\circ} \mathrm{C}$. kemudian difurnace untuk mendapatkan arang dengan suhu $400{ }^{\circ} \mathrm{C}$. arang yang diperoleh diayak menggunakan ayakan 200 mesh karena luas permukaan yang semakin besar tingkat penyerapan semakin tinggi. Setelah itu ditambahkan $\mathrm{HCl}$ untuk pengkatifan arang aktif pada tongkol jagung.

Konsentrasi $\mathrm{HCl}$ pada aktivasi arang aktif mempengaruhi kemampuan adsorpsi pada arang tersebut. Kepekatan konsentrasi $\mathrm{HCl}$ yang terlalu tinggi yang dapat merusak pori-pori karbon pada karbon aktif sehingga daya adsorpsi dari karbon aktif akan menurun, bahkan efektivitasnya menurun. Sedangkan, kepekatan konsentrasi $\mathrm{HCl}$ yang kurang, tidak mampu membuka pori-pori pada karbon, sehingga daya adsorpsi karbon aktif masih kurang baik (Khery et al., 2013)

\section{Tingkat kesadahan di lingkungan Kecamatan Cepu.}

Penelitian dilakukan untuk menganalisis kadar kesadahan total pada air sumur di lingkungan kantor PPSDM Migas Cepu dengan total yaitu 3 sampel air sumur. Pengambilan sampel dilakukan secara total sampling. Menurut departemen water treatment di PPSDM Migas Cepu air sumur tidak dapat digunakan untuk minum karena pada pengolahan menimbulkan endapan putih pada bak pengolahan air. Karena diketahui kesadahan yang tinggi bisa menyebabkan banyak penyakit yang timbul didalam tubuh. Air tanah pada daerah penelitian mempunyai tingkat kesadahan yang beragam.

Berdasarkan klarifikasi kesadahan air sumur di daerah penelitian termasuk dalam kategori sadah. Besarnya konsentrasi kesadahan air sumur di daerah penelitian dapat dilihat pada Tabel 1 . Tingginya konsentrasi kesadahan yang masuk dalam kategori sadah. Kondisi pada air sumur tersebut disebabkan pada kondisi batuan yang terdapat dalam tanah di Kecamatan Cepu. Batuan penyusunan utama merupakan batuan sedimen klastis terutama batuan kapur. Batuan kapur adalah batuan dengan kalsium karbonat atau batuan yang komponen utamanya berupa lumpur yang terkandung pada variabel tanah liat (Setyaningsih, 2014).

Tabel 1. Tingkat Kesadahan Sebelum Perlakuan Adsorben.

\begin{tabular}{ccc}
\hline $\begin{array}{c}\text { Nomor } \\
\text { Sampel }\end{array}$ & $\begin{array}{c}\text { Kesadahan } \\
\text { Air }\end{array}$ & $\begin{array}{c}\text { Tingkat } \\
\text { Kesadahan }\end{array}$ \\
\hline $\mathbf{1}$ & $343,312 \mathrm{mg} / \mathrm{L}$ & Sadah \\
\hline $\mathbf{2}$ & $345,308 \mathrm{mg} / \mathrm{L}$ & Sadah \\
\hline $\mathbf{3}$ & $344,509 \mathrm{mg} / \mathrm{L}$ & Sadah \\
\hline
\end{tabular}

Berdasarkan Peraturan pemerintah Kesehatan No. 907 Tahun 2002 tentang standar tetapan kualitas air bersih dan air minum, standar baku maksimal kadar kesadahan dalam air adalah $500 \mathrm{mg} / \mathrm{L}$. Hasil yang diperoleh dalam tabel, rata-rata keadaan kesadahan pada semua sampel masuk dalam kategori sadah dan tingkat kesadahannya tidak melebihi ambang batas maksimal yang ditetapkan pemerintah. Kadar kesadahan pada air tersebut masih layak untuk dikonsumsi.

Adsorpsi kesadahan dengan arang aktif tongkol jagung

Tabel 2. Kadar Kesadahan Total Setelah Perlakuan Menggunakan Arang Aktif Limbah Tongkol Jagung

\begin{tabular}{cccc}
\hline No & Nomor & \multicolumn{2}{c}{$\begin{array}{c}\text { Rata-rata kadar } \\
\text { sesadahan }\end{array}$} \\
\cline { 3 - 4 } & & $\begin{array}{c}\text { Sebelum } \\
\text { filtrasi }\end{array}$ & $\begin{array}{c}\text { Setelah } \\
\text { filtrasi }\end{array}$ \\
\hline 1. & Sampel 1 & 343,312 & 216,566 \\
\hline 2. & Sampel 2 & 345,308 & 217,564 \\
\hline 3. & Sampel 3 & 344,509 & 216,166 \\
\hline
\end{tabular}


Kadar kesadahan air tanah dari hasil
penelitian dengan penyaringan menggunakan karbon aktif diperoleh kadar tertinggi $217,546 \mathrm{mg} / \mathrm{L}$ dan terendah $216,166 \mathrm{mg} / \mathrm{L}$. Hasil rata-rata dari 3 sampel sebesar 216,765 mg/L. Berkurang 15\% tingkat kesadahan sebelum dengan diberikan perlakuan menggunakan arang aktif.

Adanya penurunan tingkat kesadahan air sumur setelah perlakuan adsorben arang aktif metode arang celup dengan kantong teh disebabkan karena adanya aktivitas adsorpsi. Adsorpsi dipengaruhi oleh ikatan kimia dan fisika dimana molekul meninggalkan larutan dan menempel pada permukaan adsorben

Ikatan fisika terjadi karena adanya gaya van deer walls. Prosesnya berlangsung pada reaksi bolak-balik. Karena ikatan yang dihasilkan sangat lemah, mudah sekali untuk putus apabila konsentrasi zat terlarut adsorpsi dinaikan. Gaya Tarik antar molekul zat terlarut pada arang aktif, jika lebih besar dari gaya tarik pada molekul pelarut maka zat terlarut yang diuji akan teradsorpsi. Ikatan kimia dengan melihat ikatan antara zat terlarut yang teradsorpsi dan adsorben sangat kuat, sehingga sulit untuk dilepaskan dan proses hampir tidak mungkin untuk bolak-balik (Rahma, 2013).

Hasil pengujian menunjukan penggunaan karbon aktif tongkol jagung memberikan pengaruh terhadap penurunan tingkat kualitas kesadahan air tanah. Penelitian ini sesuai dengan penelitian Azwar (2018), menjelaskan bahwa arang aktif tongkol jagung mampu mengurangi polutan pada limbah ampas tahu berupa amonia, nitrit, dan nitrat (Amin, Sitorus and Yusuf, 2016).

\section{Simpulan}

Berdasarkan hasil penelitian yang diperoleh adsorben limbah tongkol jagung dengan metode arang celup dalam menurunkan kadar kesadahan total. Perlakuan adsorben pada konsentrasi aktivator $\mathrm{HCl} 4 \mathrm{~N}$ dengan lama waktu adsorpsi 10 menit, Kadar Kesadahan air di Kecamatan Cepu berkurang sebesar $15 \%$ dari sebelum diberikan perlakuan adsorben. Kadar rata-rata yang didapatkan setelah perlakuan pada 3 sampel sebesar 216,765 $\mathrm{mg} / \mathrm{L}$.

\section{Ucapan Terima Kasih}

Berterima kasih kepada pembimbing lapangan Kerja Praktek Bu Ervin Tri Suryandari dan PPSDM Migas Cepu yang sangat berjasa mengamanahi mahasiswa UIN Walisongo untuk Kerja Praktek disana.

\section{Daftar Pustaka}

Amin, A., Sitorus, S. and Yusuf, B. (2016) 'Pemanfaatan Limbah Tongkol Jagung (Zea mays) sebagai Arang Aktif dalam Menurunkan Kadar Amonia, Nitrit dan Nitrat pada Limbah Cair Industri Tahu menggunakan Teknik Celup', Jurnal Kimia Mulawarman, 13(2), pp. 7884.

CNN, Tim. (2019) Ganjar Sebut Bengawan Solo Tercemar Ciu Hingga Kotoran Babi. Diakses pada tanggal 27 Februari 2020 dari https://www.cnnindonesia.com/nasi onal/20191126193634-20-

451753/ganjar-sebut-bengawansolo-tercemar-ciu-hingga-kotoranbabi.

Khery, Y. et al. (2013) 'Efektifitas Penurunan COD Limbah Tempe Tahu Oleh Karbon Aktif Tongkol Jagung', Hydrogen: Jurnal Kependidikan Kimia, 1(1), pp. 21-27. Available at: http://ojs.ikipmataram.ac.id/index. php/hydrogen/article/view/575/5 41. 
Khopkar, S. M. (2002) Konsep Dasar Kimia Analitik. Jakarta: Universitas Indonesia Press.

Mantong, Jimmy., Argo, Bambang and Susilo, B. (2018) 'Pembuatan Arang Aktif Dari Limbah Tongkol Jagung Sebagai Adsorben Pada Limbah Cair Tahu', Jurnal Keteknikan Pertanian Tropis dan Biosistem, 6(2), pp. 100106.

Nana Ristiana, Dwi Astuti, T. P. K. (2009) 'Keefektifan Ketebalan Kombinasi Zeolit dengan Arang Aktif dalam Kadar Kedahan Air Sumur di Karangtingah Weru Kabupaten Sukoharjo', Jurnal Kesehatan, 26(1), pp. 91-102.

Rahma, B. (2013) Pengaruh ketebalan arang tempurung kelapa terhadap tingkat kesadahan air di wilayah kerja puskesmas sudu kabupaten enrekang. UIN Alaudin Makassar.

Rahmayani, F. and Siswarni, M. (2013) 'Pemanfaatan Limbah Batang Jagung Sebagai Adsorben Alternatif Pada Pengurangan Kadar Klorin Dalam Air Olahan (Treated Water)', Jurnal Teknik Kimia USU, 2(2), pp. 1-5. Available at: http://jurnal.usu.ac.id/index.php/jt k/article/view/1678.

Setyaningsih, N. (2014) 'Analisis Kesadahan Air Tanah Di Kecamatan Toroh Kabupaten Grobogan Propinsi Jawa Tengah Publikasi Karya Ilmiah', Fakultas Geografi Universitas Muhammadiyah Surakarta.

Siti Munfiah, R. M. P. A. (2015) 'Kemampuan Karbon Aktif Tongkol Jagung dalam Menurunkan Kekeruhan Air', Medsains, 1(1), pp. 30-34. 